\title{
Assessment of the Genetic Diversity in Bottle Gourd [Lagenaria siceraria (Mol.) Standl.]
}

\author{
$\operatorname{Rehan}^{1 *}$, Manoj Kumar Singh², Mukesh Kumar², Vipin Kumar², \\ Sunil Malik ${ }^{2}$ and Atar Singh ${ }^{3}$ \\ ${ }^{1}$ Department of Horticulture, College of Agriculture, J.N.K.V.V., Jabalpur (M.P.), India \\ ${ }^{2}$ Department of Horticulture, ${ }^{3}$ Department of Genetics and Plant Breeding, College of \\ Agriculture, Sardar Vallabhbhai Patel University of Agriculture and Technology, Meerut, \\ U.P, India \\ *Corresponding author
}

\section{A B S T R A C T}

\section{Keywords}

Genetic variability, Genotype, Genetic diversity, Bottle gourd

\section{Article Info}

\section{Accepted:}

10 September 2020

Available Online:

10 October 2020
The present investigation was conducted to assess the genetic variability and genetic diversity of bottle gourd Lagenaria seceraria (Mol.) Standl.] Among 24 genotypes collected from different institute/SAUs during kharif season (2018-2019). Analysis of variance showed significant variation for all traits indicating wide range of variability in genotypes. The highest genotypic and phenotypic co-efficience of variation was observed in terms of fruit girth and fruit length, which indicates that high degree of variability in these character and suggested that possibility of yield improvement through selection of this traits. High heritability coupled with high genetic advance were recorded for fruit length, fruit girth, days to first fruit harvest, and for vine length, which indicates that above characters may be most potential for further improvement. Mahalanobis D2 analysis revealed that a considerable genetic diversity was found among genotypes. Total study twenty four genotypes of bottle gourd were grouped in five clusters. The I (19 genotypes) and III ( 2 genotypes) cluster had the maximum number of genotypes. The maximum inter cluster D2 value was recorded between Cluster V and Cluster I and the minimum inter cluster D2 value was recorded in cluster V and III. The maximum inter cluster D2 values indicates that genotypes of Cluster $\mathrm{V}$ and Cluster I not closely related, whereas the genotypes of cluster II, cluster III and cluster IV were found closely related due to minimum inter cluster D2 value. The maximum contribution percentage was found with fruit length among all the characters contributed.

\section{Introduction}

Bottlegourd [Lagenaria siceraria (Mol.) Standl.] is locally known as Lauki. It is an important member of cucurbitaceous fruit vegetable and having total number of chromosome i.e., $2 \mathrm{n}=22$. It is a fast growing vine crop and originated from tropical Africa. It is well grown in both rainy and summer seasons around the world and its fruits are available in the market round year. Bottle gourd pulp is good for overcoming 
constipation, cough, and night blindness and as an antidote against certain poison (Chauhan, 1972). According to Ayurveda and Unani, it is act as cardio tonic, laxative, cooling effect, diuretic, antebellum whole some to the focus, tonic to liver, anti-periodic, antipyretic (Kirtikar and Basu, 1991). The edible portion of fruit contains 96.3 per cent moisture, 2.9 per cent carbohydrates, 0.2 per cent protein, 0.1 per cent fat, 0.5 per cent mineral matter and $11 \mathrm{mg}$ of vitamin $\mathrm{C}$ per $100 \mathrm{~g}$ fresh fruit pulp. It also contains various minerals like $\mathrm{Ca}(12 \mathrm{mg}), \mathrm{P}$ (37 mg), $\mathrm{Na}$ (1.7 $\mathrm{mg}), \mathrm{K}(87 \mathrm{mg}), \mathrm{Cr}(0.05 \mathrm{mg}), \mathrm{Fe}(0.8 \mathrm{mg})$, per $100 \mathrm{gm}$ of bottle gourd pulp (Thamburaj and Singh, 2005).

It is an annual, vigorous climbing species, monoecious and highly cross pollinated crop having wide range of genetic variability across the globe. The fruit yield of bottle gourd is the quantitative character which is dependent on many other attributes viz, vine length, node at which first female flower appeared, number of fruits per plant, fruit length, fruit weight etc. are inherited quantitatively and their expression is governed by polygenes which are highly influenced by environmental factors. Hence, selection based on yield components rather than yield itself is reliable and may be accomplished through the component approach of breeding. A specific difference in environment may have a great effect on some genotypes than others (Shaikh, et al., 2012).

Genetic improvement of any crop is largely dependent on the magnitude of a number of genetic parameters viz, phenotypic and genotypic coefficient of variation (PCV and GCV), broad sense heritability in broad sense and genetic gain; on which the breeding methods are formulated for its further improvement. Analysis on genetic variability reveals its presence and is of utmost importance as it provides clear idea for effective selection. The yield potentiality of Bottle gourd needs to be improved through an effective breeding programme. Studies on the variations of yield and yield contributing characters are important for planning of breeding program. Genetic diversity analysis among elite germplasm is prerequisite for choosing shows potential genetic diverse lines for desirable traits and to reveal genetic distinctness among genotypes.

\section{Materials and Methods}

An experiment was conducted at Horticulture Research Centre of Sardar Vallabhbhai Patel University of Agriculture and Technology, Meerut (UP) during the kharif season. The present study comprised of 24 diverse genotypes of Bottle gourd and replicated three times in a Randomized block design. The experimental field was prepared by employing one ploughing with disc harrow followed by three ploughing with cultivator and planking to make fine tilth of soil and then leveled. Fertilizers were incorporated. Before doing the layout of experimental plot, weed and other unwanted vegetation was removed from the field. Observations recorded were days to first flower initiation, days to $50 \%$ flowering, vine length $(\mathrm{cm})$, number of leaves per plant, number of primary branches per plant, days to first fruit set, days to first fruit harvest, fruit length $(\mathrm{cm})$, fruit girth $(\mathrm{cm})$, number of fruit per plant, fruit weight $(\mathrm{g})$, fruit yield per plant (kg) and duration of the crop. Heritability, genetic advance and genetic divergence were also analyzed.

\section{Results and Discussion}

The result revealed that the highest genotypic co-efficient of variation was observed (28.81) in times of fruit girth and fruit length (25.83). The moderate genotypic co-efficient of variation was observed for vine length 
(13.93), fruit yield per plant (10.92). However, low genotypic co-efficient variation was observed number of fruit per plant (5.09), fruit weight (4.24), days to first fruit harvest (2.89), number of leaves (2.30), number of primary branches (2.08), days to $50 \%$ flowering (1.84), days to first flower initiation (1.69), days to first fruit set (0.57), and duration of crop (0.36) (Table 1-5).

The highest phenotypic coefficient of variation was observed for fruit girth (29.72) and fruit length (26.18). The moderate phenotypic co-efficient of variation was observed for vine length (17.24) and fruit yield per plant (10.96). How low phenotypic co-efficient of variation was observed for number of fruit per plant (7.90), number of leaves (7.22), fruit weight (7.12), number of primary branches (5.53), days to first fruit harvest (3.56), days to first flower initiation (2.68), days to $50 \%$ flowering (1.84), duration of crop (1.84), and days to first fruit set (1.49). Further, the present finding showed that estimates of PCV were generally higher than their corresponding GCV for all the characters studied.

These findings are similar in agreement with earlier reported by Chowdhury and Sharma (2002), Kumar and Syamal (2009), Husna et al., (2011), Prasad et al., (1993). The difference among the genotypic coefficient of variance and phenotypic coefficient of variance value for different characters indicated that PCV was higher than the GCV influence of environment in expressing the variability with traits. Less difference accounts for the fact that environment is much affecting the variable performance of the characters.

The data revealed that the broad sense heritability ranged from $3.90 \%$ for duration of crop to $95.70 \%$ for fruit length. High heritability in broad sense was obtained from fruit length $(95.70 \%)$, fruit girth $(91.00 \%)$, days to first fruit harvest $(66.10 \%)$, and for vine length $(65.40 \%)$. The moderate heritability was observed for days to $50 \%$ flowering (47.80\%), number of fruit per plant $(41.50 \%)$, days to first flower initiation and fruit yield per plant $(39.90 \%)$, fruit weight $(35.90 \%)$. However low h2 value was exhibited by days to first fruit set $(14.80 \%)$, number of primary branches $(14.20 \%)$, number of leaves $(10.10 \%)$ and $(3.90 \%)$ for duration of crop. Similar result was also find earlier by Dora et al., (2003), Rahman et al., (1986), Randhawa et al., (1975), Sharma et al., (1966). The high heritability denotes high proportion of genetic effects in the determination of these characters and can be adopted for improving fruit yield. Fruit yield the character showing high heritability could be owing to greater contribution of additive genetic components in the inheritance of these attributes.

The data showed that the genetic advance expressed as percentage of mean was high for fruit girth (36.95), fruit length (31.90) and for vine length (23.21). while low genetic advance was observed for fruit yield per plant (9.00), number of fruit per plant (6.75), fruit weight (5.19), days to first fruit harvest (4.85), days to $50 \%$ flowering (2.62), days to first flower initiation (2.20), number of primary branches (1.62), Number of leaves (1.51) days to first fruit set (0.45) and (0.15) for duration of crop. Some of these characters have been also reported by (Ram et al., 2005, Rahman et al., 1986).

The cluster mean for fourteen character under study has been presented in table 2 and revealed that the days to $50 \%$ flowering and vine length were observed highest mean value for cluster $\mathrm{V}$ i.e., (48.33) and (490.98) and lowest mean value for same character observed in cluster II and cluster IV (45.00) and (361.90), respectively. The days to first 
flower initiation showed highest mean value i.e. (44.48) and lowest mean value (41.77) found in cluster V and cluster II respectively. The another character like days to first fruit set showed highest mean value in cluster III and lowest mean value in cluster IV i.e. (48.00) and (45.55) respectively. Days to first fruit harvest showed highest mean value in cluster V and lowest in cluster III (60.11) and (52.72) respectively. The fruit length was showed highest mean value i.e. (42.14) and lowest mean value (17.96) found in cluster I and cluster $\mathrm{V}$. The another character like fruit girth was observed that highest mean value (12.29) and lowest mean value (5.77) was found in cluster $\mathrm{V}$ and cluster IV. In case of number of fruit per plant highest mean value (9.50) and (7.99) found cluster $\mathrm{V}$ and cluster IV respectively.

The yield and yield attributing character like fruit weight showed highest mean value (955.00) and lowest mean (773.50) was found in cluster IV and cluster III. Another character like fruit yield per plant highest mean value (6.37) and lowest (4.88) was found in cluster IV and cluster I. in other character like duration of crop highest mean value (113.44) and lowest (109.88) was found in cluster V and cluster III respectively.

The genetic divergence analysis was done by using Mahalanobis D2 statistics and the twenty four genotypes were grouped into five different genetic clusters on the basis of genetic affinity or diversity by Tocher's methods.

Cluster I comprised of 19 genotype named, NDBG-4, VRBG-15-1, VRBG-61, VRBG15-2, VRBG-71, IC-594545, Mahima Hybrid, Pant Hybrid-4, Hazari -4000, BG- Kaveri, Ketan, warad, VRBG-16-13, NDBG-613-4, Kashi Ganga, Narendra Rashmi, Pusa Samridhi.
Cluster II comprised of 1 genotype named, Rajendra chamatkar.

Cluster III comprised of 2 genotype named, IC-594544, Pusa Naveen.

Cluster IV comprised of 1 genotype named, Narendra Dharidar-1.

Cluster V comprised of 1 genotype named, Pusa Santushti.

It was concluded that in general, there was parallelism between genetic and geographical diversity. The view point has been supported by the work of (Ghai et al., 2005, Mathew et al., (2001), Banik (2003), Islam (2004), Kabir (2007), Devi et al., (2013).

The mean inter and intra-cluster D2values are presented in table 4. The maximum inter cluster D2 value (16.09) was recorded between Cluster $\mathrm{V}$ and Cluster I and the minimum inter cluster D2 value (12.12) was recorded in cluster V and III. The intra cluster distance were found in cluster III (3.883) followed by cluster I (3.850), cluster II (3.786), cluster V (3.783), cluster IV (3.146). The maximum inter cluster D2 values indicates that genotypes of Cluster $\mathrm{V}$ and Cluster not closely related, whereas the genotypes of cluster II, cluster III and cluster IV were found closely related due to minimum inter cluster I D2 values.

It is apparent therefore, the genotypes of cluster do not differ significantly with regards to their relative genetic distance as indicated from low variation of D2 values. It is apparent therefore, the genotypes of cluster do not differ significantly with regards to their relative genetic distance as indicated from low variation of D2 values (Khatun et al., 2010, Visen et al., 2015, Kabir, 2007, Choudhary et al., 2011, Devi et al., 2013). 
Table.1 Estimates of variability

\begin{tabular}{|c|c|c|c|c|c|c|c|}
\hline Characters & $\begin{array}{c}\text { General } \\
\text { mean }\end{array}$ & Range & PCV \% & GCV \% & Heritability \% & GA & GA as \% \\
\hline Vine length & 410.54 & $158.64-510.10$ & 17.24 & 13.93 & 65.40 & 95.28 & 23.21 \\
\hline No. of leaves & 28.27 & $24.22-32.22$ & & 2.30 & 10.10 & 0.43 & 1.51 \\
\hline No. of primary branches & 11.96 & $11.00-13.11$ & 5.53 & 2.08 & 14.20 & 0.19 & 1.62 \\
\hline Days first flower initiation & 43.50 & $41.77-45.55$ & 2.68 & 1.69 & 39.90 & 0.96 & 2.20 \\
\hline Days to $50 \%$ flowering & 47.24 & $45-49.33$ & 2.66 & 1.84 & 47.80 & 1.24 & 2.62 \\
\hline Days to first fruit set & 47.14 & $45.55-48.67$ & 1.49 & 0.57 & 14.80 & 0.21 & 0.45 \\
\hline Days to first fruit harvest & 57.45 & $52.11-60.11$ & 3.56 & 2.89 & 66.10 & 2.78 & 4.85 \\
\hline Fruit length & 39.60 & $17.96-43.95$ & 26.18 & 25.83 & 95.70 & 12.63 & 31.90 \\
\hline Fruit girth & 6.57 & $5.67-12.29$ & 29.72 & 28.81 & 91.00 & 2.43 & 36.95 \\
\hline No. of fruit/plant & 8.36 & $7.33-10.22$ & 7.90 & 5.09 & 41.50 & 0.57 & 6.75 \\
\hline Fruit weight & 868.29 & $749.22-973.33$ & 7.12 & 4.24 & 35.40 & 45.04 & 5.19 \\
\hline Fruit yield/plant & 5.02 & $4.23-6.37$ & 10.96 & 10.92 & 39.90 & 0.45 & 9.00 \\
\hline Duration of the crop & 112.80 & $107.78-116.11$ & 1.83 & 0.36 & 3.90 & 0.17 & 0.15 \\
\hline
\end{tabular}

Table.2 Cluster mean

\begin{tabular}{|c|c|c|c|c|c|c|c|c|c|c|c|c|c|}
\hline $\begin{array}{l}\text { Traits / } \\
\text { Clusters }\end{array}$ & $\begin{array}{c}\text { Days to } \\
\text { first } \\
\text { flower } \\
\text { initiation }\end{array}$ & $\begin{array}{c}\text { Days to } \\
50 \% \\
\text { flowering }\end{array}$ & $\begin{array}{c}\text { Days to } \\
\text { first fruit } \\
\text { set }\end{array}$ & Vine length & No. of leaf & $\begin{array}{c}\text { No. of } \\
\text { primary } \\
\text { branches }\end{array}$ & $\begin{array}{c}\text { Days to } \\
\text { first fruit } \\
\text { harvest }\end{array}$ & $\begin{array}{l}\text { Fruit } \\
\text { length }\end{array}$ & Fruit girth & $\begin{array}{l}\text { No. of } \\
\text { fruit/ } \\
\text { plant }\end{array}$ & $\begin{array}{c}\text { Fruit } \\
\text { weight }\end{array}$ & $\begin{array}{c}\text { Fruit } \\
\text { yield/plant }\end{array}$ & $\begin{array}{l}\text { Duration } \\
\text { of the } \\
\text { crop }\end{array}$ \\
\hline Cluster-I & 43.65 & 47.46 & 47.21 & 405.83 & 28.31 & 12.03 & 57.85 & 42.14 & 6.32 & 8.22 & 872.42 & 4.88 & 113.29 \\
\hline Cluster-II & 41.77 & 45.00 & 46.55 & 405.13 & 30.22 & 11.66 & 54.33 & 36.26 & 6.76 & 8.22 & 845.55 & 5.42 & 109.89 \\
\hline $\begin{array}{c}\text { Cluster- } \\
\text { III }\end{array}$ & 43.14 & 46.50 & 48.00 & 442.33 & 28.66 & 11.11 & 52.72 & 27.22 & 6.39 & 9.50 & 773.50 & 5.21 & 109.28 \\
\hline Cluster-IV & 41.78 & 45.67 & 45.55 & 361.90 & 24.22 & 12.77 & 59.66 & 41.08 & 5.77 & 7.99 & 955.00 & 6.37 & 112.89 \\
\hline Cluster-V & 44.88 & 48.33 & 46.22 & 490.48 & 28.78 & 11.66 & 60.11 & 17.96 & 12.29 & 9.33 & 915.55 & 5.40 & 113.44 \\
\hline
\end{tabular}


Table.3 Clustering pattern

\begin{tabular}{|c|c|c|}
\hline $\begin{array}{l}\text { Clusters } \\
\text { numbers }\end{array}$ & $\begin{array}{l}\text { Number of } \\
\text { genotypes }\end{array}$ & Genotypes name \\
\hline Cluster I & 19 & $\begin{array}{c}\text { NDBG-4, VRBG-15-1, VRBG-61, VRBG-15-2, VRBG-71, IC-594545, } \\
\text { Mahima Hybrid, Pant Hybrid-4, Hazari -4000, BG-Kaveri, Ketan,Warad, } \\
\text { VRBG-16-13, NDBG-613-4, Kashi Ganga, Narendra Rashmi, Pusa }\end{array}$ \\
\hline Cluster II & 1 & Samridhi. \\
\hline Cluster III & 2 & Rajendra Chamatkar \\
\hline Cluster IV & 1 & IC-594544 and Pusa Naveen \\
\hline Cluster V & 1 & Narendra Dharidar-1 \\
\hline & & Pusa Santushti \\
\hline
\end{tabular}

Table.4 Inter and Intra cluster distance

\begin{tabular}{|c|c|c|c|c|c|}
\hline Clusters & Cluster I & Cluster-II & Cluster-III & Cluster-IV & Cluster-V \\
\hline Cluster I & $\mathbf{3 . 8 5 0}$ & 5.491 & 9.642 & 5.960 & 16.09 \\
\hline Cluster-II & & $\mathbf{3 . 7 8 6}$ & 5.782 & 5.061 & 13.39 \\
\hline Cluster-III & & & $\mathbf{3 . 8 8 3}$ & 8.552 & 12.12 \\
\hline Cluster-IV & & & & $\mathbf{3 . 1 4 6}$ & 14.86 \\
\hline Cluster-V & & & & & $\mathbf{3 . 7 8 3}$ \\
\hline
\end{tabular}

Table.5 Contribution of traits towards the divergence

\begin{tabular}{|c|c|c|}
\hline S.No. & Traits & Contribution \\
\hline $\mathbf{1}$ & Vine length & 9.42 \\
\hline $\mathbf{2}$ & No. of leaf & 1.09 \\
\hline $\mathbf{3}$ & No. of primary branches & 1.81 \\
\hline $\mathbf{4}$ & Days first flower initiation & 3.99 \\
\hline $\mathbf{5}$ & Days to 50\% flowering & 5.07 \\
\hline $\mathbf{6}$ & Days to first fruit set & 1.09 \\
\hline $\mathbf{7}$ & Days to first fruit harvest & 1.81 \\
\hline $\mathbf{8}$ & Fruit length & 36.59 \\
\hline $\mathbf{9}$ & Fruit girth & 5.07 \\
\hline $\mathbf{1 0}$ & No. of fruit/plant & 1.45 \\
\hline $\mathbf{1 2}$ & Fruit weight & 10.51 \\
\hline $\mathbf{1 3}$ & Fruit yield/plant & 17.39 \\
\hline & Duration of the crop & 4.71 \\
\hline
\end{tabular}


Contributions of various characters toward total genetic divergence are presented in table 5. Ranking character wise D2 value and adding the rank for each character for all the entries the variables, this contributed towards the genetic divergence. The maximum contribution percentage $(36.59 \%)$ was found with fruit length among all the characters contributed followed by fruit yield per plant $(17.39 \%)$, fruit weight $(10.51 \%)$, vine length (9.42 \%), days to $50 \%$ flowering and fruit girth $(5.07 \%)$, duration of crop (4.71\%), days to first flower initiation (3.99\%), number of primary branches and days to first fruit harvest $(1.81 \%)$, number of fruit per plant $(1.45 \%)$, number of leaves and days to first fruit set $(1.09 \%)$.

Based on genetic diversity and superiority with respect to any of traits the genotype may be identified and may be involve in crossing for obtaining high heterotic population, segregates and also may be exploited for development of hybrid in bottle gourd.

In conclusion the high heritability denotes high proportion of genetic effects in the determination of these characters and can be adopted for improving fruit yield. Fruit yield the character showing high heritability, could be owing to greater contribution of additive genetic components in the inheritance of these attributes and hence may prove useful for effective selection. Genotypes from the geographical region fall into different clusters and vice versa. This suggested that the selection of the parent for hybridization should be on genetic diversity rather than on the geographical area.

Divergence study suggested that crosses between the genetically diverse genotypes of cluster V and III. Based on genetic diversity and superiority with respect to any of traits the genotype may be identified and may be involve in crossing for obtaining desired segregates from breeding point of view in bottle gourd.

\section{References}

Banik, B.R. 2003. Variability, gene action and heterosis in snake gourd (Trichosanthes anguina L.), Journal of Plant Breeding and Genetics, 31 (2): 56-59.

Chauhan, D.V.S. 1972. Vegetable production in India. Ram Prasad and Sons, Agra.

Choudhary BR, Pandey S, Singh PK and Singh R. 2011. Genetic diversity in Hermaphrodite ridge gourd (Luffa acutangula), Vegetable Science, 38(1): 68-72.

Chowdhury, D. and Sharma, K.C. 2002. Studies on variability, heritability, genetic advance and correlation in ridge gourd, Horticultural Journal, 15(3): 53-58.

Devi, D.N. and Mariappan. 2013. Studies on genetic divergence in snake gourd (Trichosanthes anguina L.), International Journal of Horticulture and Floriculture, 1(1): 1-5.

Dora, D. K., Bahera, T. K, Acharya, G. C., Mohapatra, P. and Mishra, B. 2003. Genetic variability and character association in bitter gourd (Trichosanthes dioica Roxb.). Indian J. Hort., 60 (2): 163-166.

Ghai, T.R and Mahajan, M. 2005. Gene effects of some economic traits in okra, Crop Improvement, 31(1): 75-81.

Husna, A., Mahmud, F., Islam, M.R., Mahmud, M.A.A. and Ratna, M. 2011. Genetic Variability, Correlation and Path Co-Efficient Analysis in Bottle Gourd [Lagenaria siceraria (Molina) Standl.]. Advances in Biological Research, 5 (6):

Islam, M.R. 2004. Genetic diversity in bottle gourd, Pakistan Journal of Biological Science, 7(2): 226-229. 
Kabir, M.E. 2007. Genetic variability, correlation and path analysis of pointed gourd (Trichosanthes dioica Roxb.), Journal of Horticulture, 2(1): 34-36.

Khatun, R.M., and Rahman, M.G. 2010. Estimation of genetic diversity in Snake gourd (Trichosanthes cucumerina), Bangladesh Journal of Agriculture Research, 35(1): 95100.

Kirtikar, K.R. and Basu, B.D. 1991. Indian medicinal plants Vol. II. Lalit Mohan Basu Pub. Allahabad, India P. 116118.

Kumar, P. and Syamal, M.M. 2009. Genetic variability, heritability and genetic advance in bottle gourd, Indian Journal of Arid Horticulture, 4(2): 9597.

Mathew, A., Markose, B.L, Rajan, S. and Devi, S.N. 2001. Genetic divergence in Bottle gourd [Lagenaria siceraria (Mol) Standl.], Vegetable Science, 28 (2)

Prasad, M., Singh, M. and Srivastava, B.P. 1993. Genetic variability and correlation studies in bottle gourd. Haryana Journal of Horticultural Sciences, 22(3): 222-227.

Rahman, A.K.M.M, Das, M.K. and Haque, M.M. 1986.Varietial correlation and path coefficient in bottle gourd, Bangladesh Journal of Agriculture, 3(1).121-123.

Ram, D., Rai, M., Verma, A. and Singh, Y. 2005. Genetic variability and association analysis in Luffa sp, Indian Journal of Horticulture, 63(3): 294297.

Randhawa, A., Minhas, S. and Singh, S. 1975. Genetic variability and correlation studies in bread wheat, J. Resh Ludhi, 12(3): 213-217.

Shaikh, J.A, Kathiria, K.B and Acharya, R.R. 2012. Stability analysis for fruit yield and its component traits in bottle gourd, Vegetable Science, 39(1): 89-91

Sharma, S.K., Talukdar, P. and Barbora, M.C. 1966. Genetic divergence in brinjal, Annuals of Biology (India), 16(1): 6770.

Thamburaj, S. and Singh, N. 2005. Vegetables, Tuber crops and Spices, Directorate of Information and publications of Agriculture, ICAR, New Delhi. Pp. 271-272.

Visen, V. K., Thakur, P., Sharma, D. and Nair, S. K. 2015. Genetic divergence studies in Bottle gourd [Lagenaria siceraria (Molina) Standl.], Plant Archives, 15(2): 1175-1178.

\section{How to cite this article:}

Rehan, Manoj Kumar Singh, Mukesh Kumar, Vipin Kumar, Sunil Malik and Atar Singh. 2020. Assessment of the Genetic Diversity in Bottle Gourd [Lagenaria siceraria (Mol.) Standl.]. Int.J.Curr.Microbiol.App.Sci. 9(10): 1003-1010. doi: https://doi.org/10.20546/ijcmas.2020.910.120 